\title{
Uncovering University Students' Readiness through Their Assessment of Workplace Communication Skills
}

\author{
Joel M. Magogwe $e^{1,{ }^{*}}$, Leonard B. M. Nkosana ${ }^{1} \&$ Beauty B. Ntereke ${ }^{1}$ \\ ${ }^{1}$ Communication and Study Skills Unit, University of Botswana, Gaborone, Botswana \\ *Corresponding author: Communication and Study Skills Unit, University of Botswana, P.O Box 402454, Gaborone, \\ Botswana. Tel: 267-355-2421/7169-5346. E-mail: magogwej@mopipi.ub.bw
}

Received: June 23, 2014

Accepted: August 25, $2014 \quad$ Online Published: September 4, 2014

doi:10.5430/wje.v4n5p21

URL: http://dx.doi.org/10.5430/wje.v4n5p21

\begin{abstract}
Employers in today's competitive and challenging global world prefer employees who possess "soft skills" in addition to "hard skills" because they make an impact and create a good impression in the workplace. This study examined employment readiness of the University of Botswana (UB) students who took the Advanced Communication Skills (GEC 213) course in 2013. It also explored their perceptions on the importance of these skills. A triangulation approach was used involving a survey and interview to explore issues pertinent to the study questions. Ninety (90) students enrolled for the GEC 213 course completed a questionnaire and six (6) were interviewed face to face. The study found that the students regarded the skills taught in GEC 213 as very important and that more students should be enrolled in this course. The study suggests the infusion of these skills in other courses in the University, and that workshops should be conducted for all the other teaching staff on how to infuse communication and other soft skills in their courses. The study therefore recommends more research to get the views of employers regarding the readiness of the UB graduates for employment and for using soft skills. It also recommends a study comparing the perceptions of the employees with those of the University of Botswana students with regard to the students' readiness for employment.
\end{abstract}

Keywords: university; students; readiness; communication; workplace; skills

\section{Introduction}

Employers in today's competitive and challenging global world prefer employees who possess "soft skills" in addition to "hard skills" because they make an impact and create a good impression in the workplace. According to Rouse (2011) hard skills will get you an interview but you need soft skills to get the job and keep it. Rouse (2011) points out that soft skills are personal attributes that enhance interactions, job performance and career prospects.

There are many examples of soft skills, but the ones preferred by most employers and defined in this study include:

1) Good communication skills - these include the power to effectively communicate with anyone and to build collaborative relationships to gain a competitive advantage and gain the employers' confidence. Communication skills also include listening skills, oral communication, writing skills, and the ability to ask questions.

2) Organisational skills - these include time management and the ability to prioritise tasks and organise field notes and reports.

3) Personal skills - these include optimism, good manners and social etiquette, assertiveness, self-confidence, self-motivation, self-control, willingness to learn and achievement orientation.

4) Interpersonal skills - these include negotiation skills, the ability to work as a team or to collaborate with different personalities productively and effectively, and the confidence to lead.

5) Cultural sensitivity - this includes understanding and appreciating other cultures.

6) Personnel skills - these include problem solving skills or crisis management, team work, work ethic, ability to accept and learn from criticism, tenacity and values, and flexibility or adaptability, which includes the ability to 
change course and be open to new ideas and to work well under pressure.

7) Computer literacy - this refers to being able to use computers and related technology efficiently to word process, research and organise and format information.

Doyle (2014) also asserts that employers typically look for two sets of skills, hard skills and soft skills. Hard skills are teachable abilities or skill sets that are easy to quantify. Examples of hard skills include:

1) Proficiency in a foreign language

2) A degree or certificate

3) Typing speed

4) Machine operation

Soft skills, on the other hand, are subjective skills that are much harder to quantify. Also known as "people skills" or "interpersonal skills," soft skills relate to the way you relate to and interact with other people. Examples of soft skills include:

1) Communication

2) Teamwork

3) Flexibility

4) Patience

5) Time management

6) Motivation

Communication seems to be the main soft skill since all the other ones seem to have something to do with it. For instance for one to work well within a team they have to be a good communicator and others like time management, patience, flexibility and motivation are part of non-verbal communication.

Communication is a process through which information such as policies, procedures, finance and customer feedback (Vandenberg et al., 1999) is conveyed to members of an organisation, stakeholders, customers and friends. The quality of the messages and the feedback is determined by the effectiveness of the communication process (Dainton $\&$ Zelley, 2005). Communication impacts the credibility and relationship of the communicators or members of the organisation. The interpersonal communication skills of all members of the organisation therefore contribute to the effectiveness of the communication (Devito, 1996).

Interpersonal communication has been investigated through a variety of measures that touch on interpersonal communication skills. For example, the Communication Satisfaction Questionnaire (CSQ), a popular instrument for analysing communication processes in organisations. Research findings have shown that interpersonal communication skills are important in managing people (Boyatzis, 1982; Whetten \& Cameron, 2002), and in handling conflicts, running meetings, team building and promoting change. Specific interpersonal communication variables have also been researched. For example, Penley and Hawkins (1985) have studied communication responsiveness of supervisors (listening and responding to issues), and personal communication (discussed personal issues with subordinate); and Guzley (1992) studied superior/subordinate communication (two way communication).

\section{Importance of Soft Skills}

Fleming (2013) reported that more than $75 \%$ of employers surveyed said that soft skills were as important as - or more important than - technical skills, but research also indicated that many applicants were missing even the basic soft skills of communication and professionalism. Studies done in the USA and Australia (Meier et al., 2000, Sageev \& Romanowski, 2001) consistently identified communication and team work as essential skills. Gabric and Mcfadden (2000) investigated students' perceptions of the expected marketable skill base and found that the students agreed that communication and time management skills were transferable and relevant for many career-related situations and could make them more employable and educated. Oral and written communication skills were found to be important for employment (Clark, 1990; Nelson et al., 1996; Morgan, 1997; DeLange et al., 2006). According to Pekker (2013), at Buehler Products, employees willing to present proposals are more positioned for advancement, meaning that oral presentation skills lead to promotions.

In this study the Uncertainty Reduction Theory and the Social Penetration Theory underpin the importance of soft 
skills in the workplace. According to the Uncertainty Reduction Theory by Berger and Calabrese (1975), people reduce uncertainty by soliciting information from other people and attempting to fit in the group through communication strategies such as:

1) Passive observation, in which people watch how others act;

2) Active information gathering, in which people find out information from third-party sources;

3) Direct interaction, in which people deal directly with whomever or whatever group they want to know more about.

On the other hand, in the Social Penetration Theory Altman and Taylor (1973) postulate that interpersonal skills are valuable for fitting into a new environment because as relationships develop they move from non-intimate shallow levels to deeper more intimate levels. Scholars have used this theory to explore the development of counter-sex/romantic relationships, friendships, parent-child relationships and employer-employee relationships. This theory is essential for helping new employees build relationships and become successful in the workplace. According to Eisenberg and Goodall (2004), positive interpersonal relationships are a prerequisite for effective job performance and they provide social support and sense of identification to the employees. The Uncertainty Reduction Theory and the Social Penetration Theory are used in this research as they seem to be the most appropriate for a study that considers the importance of communication skills and other soft skills in the workplace for the University of Botswana students.

\section{Purpose of the Study}

This study examined employment readiness of the University of Botswana students who took the Advanced Communication Skills course in 2013. It also explored their perceptions on the importance of these skills. This study was motivated by the research findings which show that students in many countries lack soft skills. For example, in the USA a survey of employers and postsecondary administrators found that unfortunately too many students applying for work in industries such as health-care, manufacturing and professional services lacked soft skills (Fleming, 2013). Birrell (2006) indicates that employers are seeking a diverse range of skills and attributes in new graduates despite the fact that many countries are facing a skills shortage in the area. Mangum (1996) also indicates that one of the greatest shortcomings of job candidates reported by employers was poor communication skills.

In the Botswana context this study is essential because it is the first of its kind as far as the authors know. Botswana is a landlocked country located in Southern Africa comprising approximately two million people. The study also responds to a dearth of studies on this topic because as Athiyaman (2001) indicates, there are few studies which acknowledge the views that students about to enter employment might have about the skills and attributes required in entry level graduates, despite the fact that they are key stakeholders in the whole process.

\section{Research Questions}

1) Do the students think that communication skills are important for career success?

2) Which skills are considered important in the work place by the students?

3) Are the students well equipped with these skills in readiness for the world of work?

4) What are the differences between Faculties and Genders in terms of the importance of communication skills in the work place?

\section{Methodology}

A triangulation approach was taken by this study involving a survey and interview to explore issues pertinent to the study questions. Ninety (90) students enrolled for a semester long Advanced Communication Skills Course at the University of Botswana completed a questionnaire and six (6) were interviewed face-to-face. A small sample of interviewees was used because, according to Lincoln and Guba (1985), a few interviewees can generate an enormous amount of useful data, and larger sample sizes do not add significantly to the research findings. Furthermore, Martin, Maytham, Case and Fraser (2005) indicate that interviews allow for interaction with interviewees and a more in-depth exploration of their answers to the questions. The interview data was analyzed to generate answers to the questions asked. 
$42.2 \%(\mathrm{~N}=38)$ of the students who completed the questionnaire came from the Humanities Faculty; $23.3 \%(\mathrm{~N}=21)$ from Business; $18.9 \%(\mathrm{~N}=17)$ from Education; $14.4 \%(\mathrm{~N}=13)$ from Social Sciences; and $1.1 \%(\mathrm{~N}=1)$ from Science. The Faculties of Engineering and Health Sciences were not represented because students did not register for the optional Advanced Communication Skills Course for reasons beyond the authors' control. Sometimes students find the registration closed because this course is popular. Questions for the questionnaire used in this study were selectively borrowed from Leggett, Kinnear, Boyce, and Bennett (2004) and Kavanagh and Drennan (2008) and reworded by the authors to suit objectives of the study and the Botswana context. These questionnaires had also been validated previously and were also found to be asking similar questions asked by this study.

The students completed demographic information such as gender, age and faculty; and they were assured that the questionnaire was anonymous and that they should not write their names or any other comments that would make them identifiable. Part A of the questionnaire identified some key skills and instructed the students to rate their perceptions on the importance of the skills to the workplace on a scale of 0 (represents a skill considered to be of no importance) to 3 (represents a very valuable and important skill). Part B consisted of open-ended questions to add to the skills that would have been missed out on the list of skills in the questionnaire. The questionnaire data was anlaysed for frequencies and means using SPSS.

\section{Findings and Discussion}

The first research question for this study sought to find out if the students thought that professional communication skills were important for career success. 95.6 \% ( $\mathrm{N}=87)$ thought the skills were important because they chose 'Yes' for the answer. Only 4.4\% ( $\mathrm{N}=4)$ said 'No' meaning that they did not think the skills were important. In terms of the Likert Scale, $(0=$ not important; 1 = least important; 2 =important; 3 =Very important $)$, the overall mean for the variables was $2.81(\mathrm{~N}=90)$, meaning that the students thought the skills were very important because the mean is closer to 3 than to 2 .

Students gave the following reasons for the importance of communication skills:

Student 1: Communication is important because it is done everywhere. Communicating professionally relays the message without barriers and misinterpretation.

Student 2: $\quad$ It helps people to work in a harmonised environment.

Student 3: It educates us on how to communicate in a good manner and reduces conflicts on how certain people would address others.

Student 4: $\quad$ There would be no proper execution of tasks or duties without effective communication or understanding of roles.

Student 5: $\quad$ To survive in the real world you need to have professional communication skills.

Student 6: We were exposed to different issues that made us aware of how to handle issues at the work place which will be very useful.

Student 7: It helps improve our communication skills as we are able to communicate well with people of different backgrounds.

Student 8: $\quad$ Such skills help differentiate you from other workers and this puts you in more of an advantage in the industry.

Student 9: Communication is a vital part of involvement and participation in the workplace, hence without it organisational performance is negatively affected therefore career success.

Student 10: $\quad$ They are important because they promote self-actualisation and help individuals to develop as we as contribute towards the success and forming of friendships and good relations.

The interviewed students emphasized that good communication skills increased the chances of sponsorship. They said the communication skills courses also improved their presentation, research and interpersonal skills. One of them said, "The world of work is all about communicating, exchanging ideas and sending and receiving information. Lack of effective communication can impede productivity, bad relationships; and poor communication can tint the good name of the organization." This view agrees with Dainton and Zelly's (2005) view that the effectiveness of communication is defined by the quality of the messages and the feedback. Another interviewee said that communication skills and other soft skills should be infused in all the other courses so that all students may have the opportunity to learn them and not just those who opt to take the Advanced Communication Skills course. 
The second research question asked the students to indicate the skills they considered important in the work place. Organisational skills were chosen with the highest mean of $2.93(\mathrm{~N}=90, \mathrm{~S}=0.171)$ and the least were cultural skills $(\mathrm{M}=2.62, \mathrm{SD}=0.363, \mathrm{~N}=90)($ Table 1$)$.

Table 1. List of Skills by Importance

\begin{tabular}{lccc}
\hline & Mean & $\begin{array}{c}\text { Standard } \\
\text { Deviation }\end{array}$ & Number \\
\hline Organisational skills & 2.93 & .171 & 90 \\
Personal skills & 2.86 & .239 & 90 \\
Computer skills & 2.84 & .235 & 90 \\
Communication skills & 2.84 & .256 & 90 \\
Leadership skills & 2.85 & .255 & 90 \\
Appreciative skills & 2.80 & .296 & 90 \\
Personnel skills & 2.80 & .279 & 88 \\
Research skills & 2.77 & .343 & 90 \\
Cultural skills & 2.62 & .363 & 90 \\
\hline
\end{tabular}

Means were also computed for each category of skills and the following was found:

\subsection{Computer Skills}

All the four skills in this category scored the mean score above 2.80, except 'Presenting written material in an attractive form' (Table 2).

Table 2. List of Computer Skills by Importance

\begin{tabular}{llccc}
\hline & & Mean & $\begin{array}{c}\text { Standard } \\
\text { Deviation }\end{array}$ & Number \\
\hline 1. & Computer use: word processing & 2.89 & .348 & 90 \\
2. Presenting written material in an attractive form & 2.88 & .362 & 90 \\
3. Finding information using a computer & 2.88 & .362 & 90 \\
4. & Computer use: graphs and data analysis & 2.75 & .485 & 90 \\
\hline
\end{tabular}

\subsection{Organisational Skills}

Both skills scored very high or were regarded as almost very important $(\mathrm{M}-2.93)$. See Table 3.

Table 3. List of organisational skills by importance

\begin{tabular}{llccc}
\hline & & Mean & $\begin{array}{c}\text { Standard } \\
\text { Deviation }\end{array}$ & Number \\
\hline 1. & Time management & 2.93 & .254 & 88 \\
2. & Keeping organized work e.g. field notes, reports etc. & 2.93 & .252 & 89 \\
\hline
\end{tabular}

\subsection{Communication Skills}

All communication skills in this category were regarded as very important except that the students thought 'Ability to ask questions' was comparatively less important (Table 4).

Table 4. List of Communication Skills by Importance

\begin{tabular}{llccc}
\hline & & Mean & $\begin{array}{c}\text { Standard } \\
\text { Deviation }\end{array}$ & Number \\
\hline 1. & Listening skills & 2.88 & .331 & 89 \\
2. & Oral communication skills & 2.86 & .354 & 90 \\
3. & Writing skills & 2.86 & .354 & 90 \\
4. & Reading skills & 2.83 & .375 & 90 \\
5. & Ability to ask questions & 2.77 & .448 & 88 \\
\hline
\end{tabular}

6.4 Cultural Sensitivity

Although the means were comparatively lower, the students regarded all the skills in this category as very important, except the 'foreign language' skill (Table 5). 
Table 5. List of Cultural Skills by Importance

\begin{tabular}{|c|c|c|c|}
\hline & Mean & $\begin{array}{c}\text { Standard } \\
\text { Deviation }\end{array}$ & Number \\
\hline 1. Cultural sensitivity & 2.76 & .477 & 89 \\
\hline 2. Cross cultural appreciation & 2.76 & .455 & 88 \\
\hline 3. Cross cultural communication & 2.74 & .464 & 90 \\
\hline 4. Foreign language & 2.24 & .646 & 87 \\
\hline
\end{tabular}

\subsection{Leadership and Interpersonal Communication}

All the skills in this category were regarded as very important, but the 'interpersonal skills' were the highest preferred followed by 'team leadership skills' (Table 6).

Table 6. List of Leadership and Interpersonal Skills by Importance

\begin{tabular}{llrrr}
\hline & & Mean & \multicolumn{2}{c}{$\begin{array}{c}\text { Standard } \\
\text { Deviation }\end{array}$} \\
\hline 1. & Interpersonal skills & & .269 & 90 \\
2. & Team Leadership skills & 2.92 & .364 & 90 \\
3. & Negotiation skills & 2.84 & .364 & 90 \\
\hline
\end{tabular}

\subsection{Appreciative Skills}

All the skills were equally very important, except that critical thinking and continuous learning were slightly lower than others (Table 7).

Table 7. List of Appreciative Skills by Importance

\begin{tabular}{llccc}
\hline & & Mean & $\begin{array}{c}\text { Standard } \\
\text { Deviation }\end{array}$ & Number \\
\hline 1. & Decision making & & .362 & 90 \\
2. Analytical skills & 2.88 & .402 & 90 \\
3. Critical thinking skills & 2.80 & .444 & 90 \\
4. $\quad$ Continuous learning & 2.78 & .440 & 89 \\
\hline
\end{tabular}

\subsection{Personal Skills}

All skills were very important including the comparatively less important 'achievement orientation' skills (Table 8).

Table 8. List of Personal Skills by Importance

\begin{tabular}{llrrr}
\hline & & Mean & \multicolumn{2}{c}{$\begin{array}{c}\text { Standard } \\
\text { Deviation }\end{array}$} \\
\hline 1. & Assertiveness/self-confidence & 2.91 & .286 & 90 \\
2. & Self-motivation & 2.90 & .303 & 89 \\
3. & Self-control & 2.88 & .329 & 90 \\
4. Ability and willingness to learn & 2.83 & .375 & 90 \\
5. Achievement orientation & 2.78 & .441 & 88 \\
\hline
\end{tabular}

\subsection{Research and Logical}

All the skills almost equally regarded as very important (Table 9).

Table 9. List of Research and Logical Skills by Importance

\begin{tabular}{llrrr}
\hline & & Mean & \multicolumn{2}{c}{$\begin{array}{c}\text { Standard } \\
\text { Deviation }\end{array}$} \\
\hline 1. & Reading for understanding & \multicolumn{3}{c}{ Number } \\
2. & Research & 2.81 & .394 & 90 \\
3. $\quad$ Logical argument & 2.78 & .444 & 90 \\
4. $\quad$ Organising ideas & 2.75 & .459 & 89 \\
\hline
\end{tabular}




\subsection{Personnel Skills}

Problem solving skills were regarded as more important than tenacity or firmness or persistence (Table 10).

Table 10. List of Personnel Skills by Importance

\begin{tabular}{llccc}
\hline & & Mean & $\begin{array}{c}\text { Standard } \\
\text { Deviation }\end{array}$ & Number \\
\hline 1. & Problem solving & 2.89 & .316 & 90 \\
2. & Team work and cooperation & 2.86 & .384 & 90 \\
3. $\quad$ Work ethic & 2.86 & .384 & 90 \\
4. $\quad$ Values & 2.80 & .429 & 90 \\
5. $\quad$ Flexibility & 2.76 & .453 & 89 \\
6. Initiative relationship building/rapport & 2.73 & .469 & 90 \\
7. & Tenacity or firmness or persistence & 2.65 & .524 & 89 \\
\hline
\end{tabular}

The third research question sought to find out if the students were well equipped with the above skills in readiness for the world of work. $67.4 \%(\mathrm{~N}=62)$ agreed that they were well equipped and $28.3 \%(\mathrm{~N}=26)$ claimed that they were not. The students who claimed to be equipped with the communication skills gave the following reasons:

Student 1 - I have good interpersonal skills and as a result I can communicate professionally. I appreciate and acknowledge different cultures and therefore I have a better relation with individuals.

Student 2: $\quad$ I am competent in all the four communication skills and have lived to appreciate other cultures and to relate with other people.

Student 3: $\quad$ I think so because I have managed to improve my listening skills as well as my leadership skills which one needs for the field of work.

Student 4: I think that with the time I have spent in University I have been able to develop some of the skills mentioned, and I am still to work on them.

Student 5: I have learnt how to work in a group context and individually. This will assist me when in the workplace to be able to work towards individual tasks and group tasks.

Student 6: Throughout my study I always take elective courses in communication skills hence have learnt and equipped myself with the necessary communication skills.

On the other hand, those who thought they were not well equipped with the skills gave the following reasons:

Student 1 - $\quad$ I think the time is short and the material is a lot hence I do not fully understand some concepts.

Student 2: $\quad$ I still lack some of these skills and others I need to work hard on them to improve.

Student 3: I Ifeel there is need for me to still learn a lot in terms of organisational communication, and therefore I am not well equipped.

Student 4: In some areas I lack confidence like critical thinking skills and for tenacity or firmness or persistence.

Student 5: I do not believe I am ready for the world or work, some skills need to be fully developed in terms of my preparation for the business world.

Student 6: I would say I am an average communicator because there are many things I could improve on.

Interviewed students were asked whether they were well equipped to communicate in the workplace and one of them said, "I wouldn't really say I am fine. I think the GEC 213 Course that we were doing was very helpful. I liked the concept of the JOHARI Window because it taught me to take into consideration what people know about me that I did not know." Another one said that he could now debate issues well or engage at a critical level with other people. Yet another one expressed his appreciation for the impact the GEC 213 course has had on his life. He said the course had improved his human relations a lot. Through working on group projects and assignments with students from various walks of life, including international students, he now did not just have a local outlook but an international one as well. He further said that his character had grown. For instance his temper had gone down tremendously. The students were also asked to identify generic or soft skills that they thought should be emphasized at the University including writing skills, organizational communication skills and other important ones like face-to-face communication. One student said about writing, "We need writing skills because graduates write poor letters and as a result lose opportunities. Usually they are despised by employers." Another student commented thus about presentations, "I believe learning how to present is important. Presentations are very important because they teach 
you about knowing your audience and time management."

The fourth research question wanted to find out whether there were differences between Faculties and Genders in terms of the importance of communication skills in the work place.

\subsection{Faculty Comparisons}

Means of overall skills across Faculties were compared and the results show that the Humanities Faculty scored the highest mean (2.85) and the Faculty of Business the lowest (2.75). However, all the means were skewed towards the '3' or 'very important' scale of the Likert Scale (Table 11).

Table 11. Comparison of Overall Means by Faculty

\begin{tabular}{lccc}
\hline & Mean & Standard Deviation & Number \\
\hline Humanities & 2.85 & .179 & 15 \\
Social Science & 2.83 & .161 & 13 \\
Science & 2.83 & .000 & 1 \\
Education & 2.75 & .247 & 17 \\
Business & 2.75 & .206 & 21 \\
Total & 2.81 & .200 & 92 \\
\hline
\end{tabular}

\subsection{Gender Comparisons}

The results show that Mean for the Females (2.85) was higher than that of the Males (2.75) although they are both skewed towards the very important scale (Table 12).

Table 12. Comparison of Overall Means by Gender

\begin{tabular}{lccc}
\hline & Mean & Standard Deviation & Number \\
\hline Female & 2.85 & .195 & 69 \\
Male & 2.78 & .218 & 21 \\
Total & 2.81 & .200 & 90 \\
\hline
\end{tabular}

In summary, the findings of this study show that a majority of the students (95.6\%) who participated in this study viewed soft or communication skills as important $(\mathrm{M}=2.81$ - where 3 is very important) for a number of reasons. They thought communication is vital and becomes effective when there are no barriers and misinterpretations. They also said it reduces conflicts and creates a harmonised environment where people come from different backgrounds. These findings support Whetten and Cameron's (2002) view that interpersonal communication skills are important for managing people, handling conflicts and building teams. The participants in this study also emphasised that with effective communication execution of duties and understanding of roles becomes easier, and that people participate more and their careers become successful. Finally, they thought that communication improves oral presentation and interpersonal skills, and develops individuals to become self-actualised.

\section{Implications}

A number of implications arise from the findings of this study. The first implication is that more spaces should be increased so that more students can enrol for the Advanced Communication Skills Course (GEC 213) because students regard the skills taught in this course as very important. Currently there are very limited spaces in this course as the maximum number of students that can be enrolled in any one academic year is 120 due to shortage of teaching staff in the Communication and Study Skills Unit (CSSU). This course is therefore not able to cater for the communication and soft skills needs of the majority of the students at the University of Botswana. The second implication is that more soft skills should be infused in other courses in the University. One of the interviewed students indicated that infusing the soft skills in all the courses may be useful to all the students. This would mean that the CSSU should run workshops for all the other teaching staff on how to infuse communication and other soft skills in their courses. The third implication is that the following skills should be given more emphasis in the CSS curriculum because, although they were regarded as very important, they were given less preference by the students compared to the other skills: Cultural skills; research skills; computer skills; ability to ask questions; negotiation skills; continuous learning and critical thinking skills; achievement orientation; organising ideas and logical argument; and finally flexibility, rapport building; and tenacity or firmness. 


\section{Conclusions and Recommendations}

This study has shown that the students enrolled in the Advanced Communication Skills (GEC 213) course in 2013 in the CSSU appreciated the importance of communication skills and other soft skills for employment readiness. Unfortunately, only $67.4 \%$ of them agreed that they were well equipped with these skills and were ready to use them in the work place. The remaining $32.6 \%$ who thought they were not well equipped raised reasons such as that there was not enough time to learn these skills in GEC 213; and that they lacked confidence and critical thinking skills. It is imperative for the University of Botswana, through the CSSU, to extend the offering of advanced communication skills to the majority of the students to prepare them for the workplace in conjunction with the University of Botswana policy of life-long learning. This view concurs with Martin, Maytham, Case and Fraser's (2005: 68) observation that "tertiary education institutions have, in recent times, assumed the responsibility of adequately developing their students' non-technical skills for use in the workplace". It will also be interesting to find out what employers in the Botswana job market think of the graduates of the University of Botswana with regard to these skills. We therefore recommended that a study be conducted to get the views of employers regarding the readiness of University of Botswana graduates for employment, especially with regard to their possession of communication skills and other soft skills. We also recommend a study comparing the perceptions of the employees with those of the University of Botswana students with regard to the students' readiness for employment.

\section{References}

Altman, I., \& Taylor, D. (1973). Social penetration: The development of interpersonal relationships. New York: Holt, Rinehart, and Winston.

Athiyaman, A. (2001). Graduates' perceptions about business education: An exploratory research. Journal of Further and Higher Education, 25, 5-19. http://dx.doi.org/10.1080/03098770020030461

Berger, C.R., \& Calabrese, R.J. (1975). Some explorations in initial interaction and beyond: Toward a developmental theory of interpersonal communication. Human Communication Research, 1(2), 99-112. http://dx.doi.org/10.1111/j.1468-2958.1975.tb00258.x

Birrell, B. (2006). The changing face of the accounting profession in Australia, CPA Australia, November, 2006.

Boyatzis, R. (1982). The competent manager: A model for effective performance. New York: John Wiley \& Sons.

Clarke, P.J. (1990). The Present and Future Importance of Curriculum Topics Relevant to Accounting Practice: A Study of Irish Perceptions, University College Dublin.

Dainton, M., \& Zelley, ED. (2005). Applying communication theory for professional life, A practical introduction. London: Sage Accounting Practice: A Study of Irish Perceptions, University College Dublin.

DeLange, P., Jackling, B., \& Gut, A. (2006). Accounting Graduates' Perceptions of Skills Emphasis in Australian Undergraduate Accounting Courses: An Investigation from 2 Victorian Universities. Accounting and Finance, 46, 365-386. http://dx.doi.org/10.1111/j.1467-629X.2006.00173.x

Doyle, A. (2014). Hard Skills vs. Soft Skills: The Difference between Hard Skills and Soft Skills. Retrieved from http://www.jobsearch.about.com/od/skills/qt/hard-soft-skills.htm

Eisenberg, E. M., \& Goodall, H. (2004). Developing a Cultural Hermeneutic to Conflict Resolution. Retrieved from http://www.evancarmichael.com/Business-Coach/2489/Developing-a-Cultural-Hermeneutic-to-Conflict-Resolut ion.html

Fleming, K. (2013). 'Soft Skills' Are Critical for Workplace Readiness. Retrieved from http://www.wymancenter.org/soft-skills-are-critical-for-professionals/

Gabric, D., \& McFadden, K. (2000). Student and employer perceptions of desirable entry-level operations management skills. Mid-American Journal of Business, 16, 51-59.

Guzley, R. M. (1992). Organizational climate and communication climate: Predictors of commitment to the organization. Management $\quad$ Communication $\quad$ Quarterly, 579-402. http://dx.doi.org/10.1177/0893318992005004001

Kavanagh, M.H., \& Drennan, L. (2008). What skills and attributes does an accounting graduate need? Evidence from student perceptions and employer expectations. Accounting and Finance, 48(2), 279-300. http://dx.doi.org/10.1111/j.1467-629X.2007.00245.x 
Leggett, M., Kinnear, A., Boyce, M., \& Bennett, I. (2004). Student and staff perceptions of the importance of generic skills in science. Higher Education Research \& Development, 23(3), 295-312, http://dx.doi.org/10.1080/0729436042000235418

Lincoln, Y. S., \& Guba, E. G. (1985). Naturalistic Inquiry. Beverly Hills, CA: Sage Publications.

Mangum, W.T. (1996). How job seekers should approach the new job market. Journal of Career, Planning and Employment, LVI(4), 67-80.

Martin, R., Maytham, B., Case, J., \& Fraser, D. (2005). Engineering graduates' perceptions of how well they were prepared for work in industry. European Journal of Engineering Education, 30(2), 167-180. http://dx.doi.org/10.1080/03043790500087571

Meier, R.L., Williams, M.R., \& Humphreys, M.A. (2000). Refocusing our efforts: assessing non-technical competency gaps. J. Eng. Educ., July 2000, 377-385. http://dx.doi.org/10.1002/j.2168-9830.2000.tb00539.x

Morgan, G.J. (1997). Communication skills required by accounting graduates: practitioner and academic perceptions. Accounting Education, 6(2), 93-107. http://dx.doi.org/10.1080/096392897331514

Nelson, S. J., Moncada, S., \& Smith, D.C. (1996). Written language skills of entry-level accountants as assessed by $\begin{array}{lllll}\text { experienced CPA's. } & \text { Business }\end{array}$ http://dx.doi.org/10.1177/108056999605900412

Pekker, M. (2013). Self-Disclosure in Interpersonal Communication. Retrieved from http://www.interpersonal-compatibility.blogspot.com/2012/07/self-disclosure-in-interpersonal.html

Penley, L., \& Hawkins, B. (1985). Studying interpersonal communication in organizations: A leadership application. Academy of Management Journal, 28(2), 309-26. http://dx.doi.org/10.2307/256203

Rouse, D. (2011). Applying talent management principles to build OSROs' capabilities for the future. International Oil Spill Conference Proceedings, 2011(1), 139. http://dx.doi.org/10.7901/2169-3358-2011-1-139

Sageev, P., \& Romanowski, C.J. (2001). A message from recent engineering graduates: results of a survey on technical communication skills. J. Eng. Educ., 685-692. http://dx.doi.org/10.1002/j.2168-9830.2001.tb00660.x

Whetten, D.A., \& Cameron, K.S. (2002). Developing Management Skills. Englewood Cliffs, NJ: Prentice-Hall. 